\title{
Merentang Masa Depan Pendidikan di SMP Negeri 1 Lirung Melalui Peduli Lingkungan
}

\section{Adriana Niora Maalua}

SMP Negeri 1 Lirung

nioramaalua@gmail.com

\section{Article History}

accepted 01/12/2020

approved 01/01/2021

published 01/03/2021

\begin{abstract}
The school environment has an important role in the learning process. The problem experienced in SMP Negeri 1 Lirung is that the scholl environment has not fully become a source of learning for learners. Based on the problem, the Adiwiyata school was trigged. The result of the program that there is a significant changes in several things like: the environment became beautiful anda shady, the growth of the character of environmental care,increased knowledge of the school members about the environment, there was a strengthening of school managemen, and school achieved achievement at the district, provincial, and national levels. Tehe environmental cara program at SMP Negeri 1 Lirung, has had a positive impact on progress and increased performance for all school members, anad can inspire other school aroun it.
\end{abstract}

Keywords: Education, Caring for the environment

\section{Abstrak}

Lingkungan dalam sekolah memiliki peran penting dalam proses pembelajaran terutama sebagai sumber belajar. Masalah yang dialami di SMP Negeri 1 Lirung, yaitu lingkungan sekolah belum sepenuhnya menjadi sumber belajar bagi peserta didik. Untuk mengatasi hal tersebut dicetuskanlah program Sekolah Adiwiyata. Hasil yang dicapai, terjadinya perubahan yang mendasar dalam hal-hal berikut: lingkungan menjadi ASRI, tumbuhnya karakter peduli lingkungan, bertambahnya wawasan warga sekolah tentang lingkungan, terjadi penguatan manajemen sekolah, dan sekolah meraih prestasi di tingkat kabupaten, provinsi dan nasional. Program peduli lingkungan di SMP Negeri 1 Lirung telah memberikan dampak terhadap peningkatan kinerja bagi seluruh warga sekolah serta dapat menginspirasi sekolah-sekolah lain yang ada di sekitarnya.

Kata kunci: Pendidikan, Peduli Lingkungan

Social, Humanities, and Education Studies (SHEs): Conference Series https://jurnal.uns.ac.id/shes 


\section{PENDAHULUAN}

Permasalahan di sekolah-sekolah cukup banyak dan bervariasi sesuai kondisi daerah. Permasalahan yang dialami oleh sekolah tentu saja membutuhkan penanganan sebab jika tidak akan berdampak terhadap prestasi sekolah. Permasalahan itu antara lainnya tentang lingkungan, karakter, pembelajaran, motivasi belajar, disiplin. Dari berbagai masalah tersebut, maka ada sejumlah solusi yang dapat dilakukan untuk mengatasi masalah tersebut, tergantung kacamata pemimpin di sekolah itu. Pemilihan program yang menjadi prioritas yang akan dilaksanakan memerlukan pertimbangan yang matang. Sebab jika kepala sekolah kurang pas mengeksekusi keputusan, akan berdampak terhadap kemajuan dan perkembangan sekolah itu.

Masalah lingkungan tidak hanya menjadi tanggung jawab masyarakat atau pemerintah saja melainkan menjadi tanggung jawab semua lapisan masyarakat termasuk sekolah. Masalah lingkungan merupakan masalah serius karena sangat mempengaruhi kehidupan dan kesejahteraan manusia. Sejak timbulnya masalah lingkungan maka sejak itu pun dicari solusi dan dilakukan berbagai upaya untuk mengatasi hal tersebut. Oleh karena itu pemerintah telah melakukan berbagai upaya antara lainnya adalah penyuluhan tentang pelestarian alam, memberikan kesadaran kepada masyarakat akan pentingnya lingkungan bagi manusia. Namun sejauh ini masalah- masalah lingkungan terus menghantui kehidupan manusia karena telah banyak menelan korban. Banjir, longsor, abrasi, pencemaran laur dan air dan sebagainya telah memberi dampak yang serius terhadap kehidupan umat manusia. Upaya yang dapat menjawab berbagai permasalahan tersebut adalah melalui pendidikan. Hal ini senada dengan ungkapan bijaksana Nelson Mandela melalui Haposan Andy, REPUBLIKA.CO.ID) yang berkata pendidikan adalah senjata yang paling ampuh untuk mengubah dunia. Berdasarkan pendapat tersebut maka sangatlah penting sekolah-sekolah hendaknya memiliki dan menerapkan program peduli lingkungan. Namun sayangnya sampai sekarang dari begitu banyak jumlah sekolah di satu daerah khususnya di Kabupaten Kepulauan Talaud yang menerapkan program peduli lingkungan hanya sekitar 4 sekolah. Padahal penanganan terhadap permasalahan lingkungan menjadi sesuatu yang urgen dan mendesak saat ini.

Menurut pengamatan penulis paling banyak sekolah tidak tertarik dengan program tersebut karena menganggap tugas sekolah hanya memberikan bekal ilmu pengetahuan dan teknogi yang sifatnya akademik kepada peserta didiknya. Kalaupun itu dilakukan hanya sebatas membersihkan lingkungan dan belum ada program secara kontinu dalam mengatasi masalah-masalah lingkungan dan pembiasaan terhadap peserta didik. Hal ini tentu memberikan tantangan tersendiri dalam dunia pendidikan kita. Apabila kondisi ini terjadi terus menerus tanpa perhatian serius maka akan menjadi bom waktu bagi kita yang mendiami bumi ini. Kita terbiasa nanti siuman setelah ada korban. Sulit melakukan upaya-upaya preventif untuk mengatasi masalah tersebut. Karena itu peserta didik perlu dibekali dengan pengetahuan tentang lingkungan hidup dan tidak kalah pentingnya adalah pembentukan karakter peserta didik tentang peduli lingkungan. Di sekolah, kita masih menjumpai sampah berserakan dimana-mana karena kurangnya kesadaran warga sekolah dalam hal membuang sampah. Peserta didik adakalanya setelah jajan membuang pembungkus snak di sembarang tempat, kurang memfungsikan tempat sampah yang telah disiapkan di tiap kelas dan di luar kelas. Perilaku tersebut akan menjadikan lingkungan sekolah yang kotor dan tidak sehat. Lingkungan sekolah memiliki peran penting dalam proses pembiasaan hal-hal yang baik dari guru kepada peserta didik. Triwiyanto (2014:16 menyatakan transmisi budaya masyarakat terjadi salah satunya di sekolah, tentunya budaya yang dianggap baik dan mencerminkan nilai- nilai masyarakat.

Masalah-masalah di atas menjadi dasar mengapa SMP Negeri 1 Lirung melaksanakan program peduli lingkungan. Tujuan program Adiwiyata di SMP Negeri 1 
Lirung adalah mewujudkan warga sekolah yang bertanggung jawab dalam upaya perlindungan dan pengelolaan lingkungan hidup melalui tata kelola yang baik dalam menunjang pembangunan yang berkelanjutan. Sulistyowati dalam Mriyatin 2019:2 mengatakan, kepedulian lingkungan hidup merupakan wuju sikap mental individu yang direfleksikan dalam perilakunya dalam hal ini lebih dikenal dengan istilahkarakter. Karakter dapat diartikan sebagai watak, tabiat, ahklak, dan kepribadian seseorang yang terbentu dari hasil internalisasi berbagai kebijakan (virtues) yang digunakansebagai landasan cara pandang berpikir dan bersikap, dan bertindak.

Selama ini telah ada sekolah yang menerapkan kegiatan peduli lingkungan yang merupakan tindak lanjut dari Kesepakatan Bersama antara Menteri Negara Lingkungan Hidup dengan Menteri Pendidikan Nasional Nomor Kep.07/MENLH/06/2005 dan Nomor 05/VI/KB/2005 tentang Pembinaan dan Pengembangan Lingkungan Hidup, yang kemudian tahun 2006 dikembangkan menjadi program Adiwiyata. Adiwiyata berarti tempat yang baik dan ideal tempat diperolehnya segala ilmu pengetahuan dan berbagai norma serta etika yang dapat menjadi dasar manusia menuju terciptanya kesejahteraan hidup dan kepada citacita pembangunan berkelanjutan. Sekolah Adiwiyata adalah sekolah yang memiliki program tentang peduli lingkungan dan melakukan pengelolaan lingkungan hidup di sekolah itu sendiri.

Sesuai dengan visi SMP Negeri 1 Lirung, Berprestasi, Berbudaya, Berkarakter dan Berwawasan Lingkungan" maka orientasi penyelengaraan pendidikan di SMP Negeri 1 Lirung diarahkan kepada pengembangan budaya, karakter dan berwawasan lingkungan. Dengan memperhatikan lingkungan sekolah dan masyarakat yang masih membutuhkan perhatian serius maka program tersebut di atas kami angkat dan canangkan sebagai program unggulan mengingat bahwa pembentukan karakter peduli lingkungan harus dilakukan sejak dini terutama di sekolah agar para siswa memiliki pemahaman dan pengetahuan yang kuat tentang lingkungan yang nantinya akan berdampak positif terhadap terbentuknya karakter peduli lingkungan siswa dan akan dapat berperan dalam pembangunan dimasa yang akan datang.

Pelaksanaan program Adiwiyata diletakkan pada dua prinsip dasar yaitu: 1) Partisipatif: Warga sekolah terlibat dalam manajemen sekolah yang meliputi keseluruhan proses mulai perencanaan, pelaksanaan, evaluasi berdasarkan tanggung jawab dan peran masing-masing. 2) Berkelanjutan: Seluruh kegiatan dilakukan secara terencana dan terus menerus secara komprehensif.

Ada 4 komponen program yang yang diterapkan di sekolah untuk mencapai sekolah Adiwiyata. Komponen-komponen tesebut adalah: (1) Kebijakan Berwawasan Lingkungan, (2) Pelaksanaan Kurikulum Berbasis Lingkungan, (3) Kegiatan Lingkungan Berbasis Partisipatif dan (4) Pengelolaan Sarana Pendukung Ramah Lingkungan. Keempat komponen tersebut dilakukan secara terpadu dan terprogram serta kontinu.

Keuntungan yang dirasakan oleh sekolah dalam mengikuti program Adiwiyata adalah : (1) Sekolah mampu mengelola perubahan sekolah melalui visi, misi dan tujuan, yang berbasis budaya sekolah dalam hal ini budaya lingkungan untuk mendukung pencapaian standar kompetensi/kompetensi dasar dan Standar Kompetensi Lulusan (SKL). (2) Terjadi peningkatan efisiensi penggunaan dana operasional sekolah melalui penghematan dan pengurangan konsumsi dari berbagai sumber daya dan energi. (3) Terciptanya sekolah berbudaya lingkungan (4) Menciptakan kebersamaan warga sekolah dan kondisi belajar mengajar yang lebih nyaman dan kondusif. (5) Menjadi wadah pembelajaran tentang nilai-nilai pemeliharaan dan pengelolaan lingkungan hidup bagi warga sekolah dan masyarakat.(6) Meningkatkan upaya perlindungan dan pengelolaan lingkungan hidup melalui kegiatan pengendalian pencemaran, pengendalian kerusakan dan 
pelestarian fungsi lingkungan di sekolah.(7) Menjadi role model bagi sekolah-sekolah lainnya dalam manajemen sekolah berbasis peduli lingkungan.(8) Mengubah perilaku warga sekolah untuk dapat melakukan budaya pelestarian lingkungan.

Metode pemecahan masalah dilakukan melalui langkah-langkah sebagai berikut : (1) perencanaan program, (2) sosialisasi program, (3) pelaksanaan program, dan (4) evaluasi program (Direktorat PSD Kemdikbud,2013:44) Strategi yang diambil dalam pelaksanaan program Adiwiyata di SMP Negeri 1 Lirung yaitu:

a. Pengembangan Kebijakan Sekolah Peduli dan Berbudaya Lingkungan, dengan kegiatan-kegiatannya:

1) Merevisi visi dan misi sekolah yang peduli dan berwawasan lingkungan.

2) Membuat kebijakan sekolah dalam mengembangkan pembelajaran pendidikan lingkungan hidup.

3) Kebijakan peningkatan kapasitas sumber daya manusia di bidang pendidikan lingkungan hidup.

4) Kebijakan sekolah dalam upaya efisiensi sumber daya alam dan energy.

5) Kebijakan sekolah untuk pengalokasian dan penggunaaan dana bagi kegiatan yang terkait dengan masalah lingkungan hidup.

6) Kebijakan sekolah yang mendukung terciptanya lingkungan sekolah yang bersih dan sehat

b. Pengembangan Kurikulum yang Berbasis Lingkungan

1) Pengembangan model belajar berbasis lingkungan dan budaya

2) Penggalian dan pengembangan materi pelajaran dan masalah lingkungan hidup yang ada di masyarakat

3) Pengembangan kegiatan kurikuler untuk meningkatkan pengetahuan dan kesadaran peserta didik tentang lingkungan hidup

c. Pengembangan Kegiatan Berbasis Partisipatif. Kegiatan-kegiatan yang dilakukan antara lain:

1) Melaksanakan kegiatan kerja bakti bersama dengan pihak-pihak terkait (TNI, alumni, masyarakat, orang tua).

2) Melaksanakan kegiatan ekstrakurikuler tentang peduli lingkungan di sekolah.

3) Menjalin kemitraan dengan berbagai pihak dalam membangun sekolah peduli lingkungan.

\section{HASIL DAN PEMBAHASAN}

Sebelum dilaksanakan program Adiwiyata di SMP Negeri 1 Lirung keadaan yang ada sebagai berikut:

1. Rendahnya kesadaran siswa dalam membersihkan lingkungan sekolah. Hal ini dapat dilihat dari banyaknya sampah di halaman sekolah, ruang kelas yang banyak debu dan kurangnya pohon pelindung yang dipelihara di sekolah.

2. Lingkungan sekolah yang belum tertata baik.

3. Belum terintergrasinya pendidikan lingkungan hidup ke dalam mata pelajaran dan kurikulum sekolah

4. Sekolah belum mengembangkan Pendidikan Penguatan Karakter (PPK) secara optimal khususnya menyangkut sikap peduli lingkungan.

5. Rencana Kerja Sekolah (RKS) dan Rencana Kegiatan dan Anggaran Sekolah (RKAS) belum sesuai analisis kebutuhan yang tertuang dalam Evaluasi Diri Sekolah (EDS) dan belum memprogramkan kegiatan berbudaya lingkungan sebagai program yang harus didanai oleh dana sekolah.

6. Masih rendahnya pengetahuan siswa tentang lingkungan hidup.

Program Adiwiyata yang dilaksanakan oleh SMP Negeri 1 Lirung dalam beberapa tahun terakhir ini telah membawa perubahan kemajuan yang sangat signifikan terutama dalam berbagai bidang yang menjadi sasaran program tersebut. Hasil yang dicapai sebagai pemecahan masalah di atas adalah: 
1. Terjadi pengembangan lingkungan sekolah yang mencakup penataan, pelestarian dan pengembangan lingkungan sekolah dengan program unggulan Adiwiyata. Siswa seluruhnya terlibat dalam kegiatan -kegiatan peduli lingkungan baik kegiatan pembiasaan di lingkungan sekolah maupun di luar lingkungan sekolah. Setiap hari siswa bergantian membersihkan ruang kelas dan lingkungan sesuai jadwal. Selain itu secara sukarela mereka ikut dalam kegiatan kerja bakti membersihkan tempat-tempat umum, pantai, tempat ibadah, penanaman pohon dan penataan taman di depan kelas, pembuatan green house, biopori dan kegiatan lainnya yang dipelopori oleh sekolah. Siswa terbiasa membuang sampah di tempatnya dan memilah sampah sesuai jenisnya. Begitu pula siswa terbiasa memanfaatkan barang bekas di daur ulang menjadi barang yang bernilai uang. Para siswa juga memiliki pengetahuan membuat pupuk kompos.

2. Lingkungan menjadi menarik terlihat ASRI dan tertata baik. Lingkungan menjadi sumber belajar bagi siswa.

3. Materi lingkungan hidup terintegrasi pada mata pelajaran dan kurikulum sesuai Kompetensi Dasar yang ada pada setiap mata pelajaran. Guru-guru menyusun RPP dan memasukkan materi lingkungan hidup dengan melihat kesesuaian Kompetensi Dasar dengan permasalahan lingkungan yang ada di sekolah maupun di masyarakat.

4. Pembentukan Pendidikan Karakter melalui kegiatan peduli lingkungan hasilnya sangat memuaskan karena dari tindakan para siswa terlihat adanya peningkatan sikap gotong royong, tanggung jawab, peka terhadap kebersihan, mandiri, hidup bersih, peka terhadap masalah-masalah lingkungan di luar sekolah, dan saling menghargai, rajin serta pedul i lingkungan.

5. Program budaya lingkungan sudah ada pengalokasian dana dalam RKAS setiap tahun. Kegiatan-kegiatan yang dibiayai adalah yang terkait dengan kegiatan peduli lingkungan. Hal ini tidak pernah dilakukan sebelumnya.

6. Dengan adanya kegiatan Adiwiyata pengetahuan siswa tentang lingkungan hidup juga bertambah luas. Mereka dapat berpikir tentang penanganan terhadap masalah lingkungan dan manfaat lingkungan hidup bagi manusia.

7. Terjadi penguatan manajemen sekolah terutama dalam hal lingkungan sekolah. Program-program yang dirancang memperhatikan kaitannya dengan kegiatan yang berhubungan dengan sikap peduli lingkungan. Kegiatan-kegiatan yang dilakukan telah memberi berdampak positif terutama kesadaran siswa terhadap lingkungan dan juga bagi masyarakat dalam menjaga kelesterian lingkungan hidup. Kegiatan yang dilakukan secara masal merupakan bentuk kampanye lingkungan hidup terhadap masyarakat.

8. Dengan pelaksanaan program Adiwiyata maka sekolah mendapat penghargaan tingkat kabupaten tahun 2016, penghargaan Adiwiyata tingkat provinsi tahun 2017, dan Adiwiyata Nasional tahun 2019. Melalui penghargaan dari pemerintah daerah dan pusat menjadi bukti bahwa sekolah telah melakukan tanggung jawab dalam hal membina generasi muda melalui kegiatan peduli lingkungan dan terutama merupakan bukti bahwa kinerja sekolah lebih baik dari sebelumnya.

9. Semakin banyak sekolah yang termotivasi mengikuti jejak SMP Negeri 1 Lirung dan sekolah menjadi terkenal karena kegiatan-kegiatan yang dilakukan antara lainnya peduli lingkungan.

\section{SIMPULAN}

Program peduli lingkungan di SMP Negeri 1 Lirung telah memberikan dampak positif terhadap kemajuan dan peningkatan kinerja bagi seluruh warga sekolah serta dapat menginsiprasi sekolah-sekolah lainnya yang ada di Kabupaten Kepulauan Talaud melakukan hal sama dalam manajemen dan pengembangan sekolah. Program budaya peduli lingkungan secara langsung telah memberi kontribusi 
SHEs: Conference Series 4 (2) (2021) 71- 76

terhadap pencapaian pemenuhan 8 Standar Nasional Pendidikan di sekolah. Begitu pula transparansi pengelolaan program Adiwiyata sekolah telah memberi dampak positif terhadap pengelolaan program sekolah secara keseluruhan.

Hal yang paling dirasakan dalam program peduli lingkungan ini adalah terbentuknya perilaku/ budaya bersih, bertanggung jawab, rajin, disiplin, gotong royong, jujur, dan santun dan lain-lain. Harapan ke depan program peduli lingkungan akan menjadi program bagi semua sekolah yang ada di Kabupaten Kepulauan Talaud sehingga akan membawa kemaslahata kehidupan bagi banyak orang.

\section{DAFTAR PUSTAKA}

Direktorat Pembinaan SD.2013. Manajemen Budaya dan Lingkungan Berbasis Sekolah.Jakarta: Kemdikbud

Andy,H.2019.Senjata Paling Hebat Untuk Mengubah Dunia adalah Pendidikan.https:// Republika.co.id>berita. Diakses pada 7Desember 2020.Pukul 19.04 WITA

Internet, diambil hari Selasa 8 Desember 2020. Pukul 08.12 WITA. Alamat www.academia.edu

Mriyatin.2019. Desain Unggul Adiwiyata Serasi Membangun Indahnya Lingkungan (Dua Sembilan) Dalam Mewujudkan Generasi Muda Peduli Lingkungan. UPTD SD Negeri Mekarjaya 29

Triwiyanto,T.2014.Pengantar Pendidikan.Jakarta: Bumi Aksara 